\section{Lembaran Sejarah}

\title{
Sejarah Hukum Maritim Kerajaan Sriwijaya dan Majapahit dalam Hukum Indonesia Kini
}

\section{SARTIKA INTANING PRADHANI}

Universitas Gadjah Mada

\begin{abstract}
The purpose of this research is to analyze the control of Sriwijaya and Majapahit Kingdom towards their maritime territory and to learn whether their control may be practiced in the regulatory on the maritime territory of Unitary State Republic of Indonesia today. It is a legal normative research which has descriptive and analytical nature. The control of Sriwijaya and Majapahit Kingdom towards their maritime territory was conducted through adat law. Maritime territory of Indonesia today is controlled by the written law created by the government and the unwritten law practiced by the people.
\end{abstract}

\section{Abstrak}

Penelitian ini bertujuan untuk mengkaji penguasaan Kerajaan Sriwijaya dan Kerajaan Majapahit terhadap wilayah maritimnya dan mempelajari praktik pengaturan wilayah maritim pada zaman Kerajaan Sriwijaya dan Kerajaan Majapahit yang dapat dipraktikkan dalam pengaturan wilayah maritim Negara Kesatuan Republik Indonesia kini. Penelitian ini merupakan penelitian hukum normatif yang bersifat deskriptif analitis. Penguasaan Kerajaan Sriwijaya dan Kerajaan Majapahit terhadap wilayah maritimnya dilakukan melalui hukum adat. Wilayah Maritim Indonesia saat ini dikuasai melalui hukum tertulis yang dibuat oleh pemerintah dan hukum tidak tertulis yang berlaku di masyarakat.
Keywords: history of law; maritime; Sriwijaya; Majapahit

Kata Kunci : sejarah hukum; maritim; Sriwijaya; Majapahit 


\section{Latar Belakang}

Negara Kesatuan Republik Indonesia (NKRI) adalah sebuah negara kepulauan yang berciri Nusantara dengan wilayah yang batas-batas dan hak-haknya ditetapkan dengan undang-undang. ${ }^{1}$ Wilayah Negara Indonesia terdiri dari perairan dan kepulauan. Luas laut NKRI sekitar 5,9 juta $\mathrm{km}^{2}$ yang terdiri dari 3,2 juta $\mathrm{km}^{2}$ perairan teritorial dan 2,7 juta $\mathrm{km}^{2}$ perairan Zona Ekonomi Eksklusif (Bill Nope, 2012: 5). Meskipun secara geopolitik berada di kawasan yang strategis dengan kekayaan alam yang melimpah dan sumber daya manusia yang besar, Indeks Pembangunan Indonesia berada di bawah Singapura, Malaysia, Brunei, Thailand, dan Filipina. ${ }^{2}$ Rendahnya Indeks Pembangunan Manusia Indonesia disebabkan oleh kurang dapat memaksimalkannya pemanfaatan sumber daya Indonesia, terutama potensi maritim.

Sejarah mencatat sebuah negara kolonial sebagai pendahulu dari NKRI pada dasarnya merupakan suatu negara yang dipaksakan untuk melindungi dan melanggengkan kolonialisme dan imperialisme, sehingga kepentingan Bangsa Indonesia terabaikan (Safri Burhanuddin, dkk, 2003:9). Berdasarkan sumber sejarah, meskipun kerajaan-kerajaan di Sumatera dan Jawa (Kerajaan Sriwijaya dan Kerajaaan Majapahit) baru tercatat sekitar abad ke-IV, bukan berarti sebelumnya pulau-pulau tersebut terbelakang, miskin, dan tidak terorganisasi secara politik karena Ramayana karya Valmiki (kurang lebih 500 SM) mencatat Yavadwipa atau Jawa telah memiliki organisasi kerajaan (Warsito Sastroprajitno, 1958: 7-8). Jawa merupakan salah satu kerajaan tertua dibandingkan catatan sejarah kerajaan lain di Nusantara, bahkan di Asia Tenggara (Warsito Sastroprajitno, 1958: 7-8). Jawa juga lebih dulu menjalin hubungan dengan Cina daripada kerajaan-kerajaan di Sumatera karena teknologi perkapalan di Jawa lebih unggul daripada kerajaan di Sumatera sehingga dapat membawa utusan-utusan dari Jawa dan Sumatera ke Cina, bukan sebaliknya (Warsito Sastroprajitno, 1958: 7-8).

Kerajaan Sriwijaya, sebagai suatu kerajaan maritim mengembangkan ciri khas tradisi diplomasi untuk mempertahankan perannya sebagai pusat perdagangan. Kekuatan utama Kerajaan Sriwijaya adalah penguasaan terhadap daerah Selat Malaka sehingga memegang kunci pelayaran perdagangan ke Cina dan negeri-negeri barat. Sektor perdagangan dan pelayaran yang menjadi sektor andalan Kerajaan Sriwijaya membutuhkan pengawasan langsung dari penguasa kerajaan. Kerajaan Sriwijaya mempunyai kekuatan angkatan laut untuk melakukan ekspedisi ke luar negeri sekaligus memastikan jalur pelayaran aman dari bajak laut.

Salah satu strategi pengamanan wilayah maritim Kerajaan Sriwijaya adalah dengan memasukkan kepala bajak laut dalam ikatan dengan kerajaan

1) Pasal 25A Undang-Undang Dasar Negara Republik Indonesia Tahun 1945.

2) http://www.kompasiana.com/rokhmin/indonesia-sebagai-poros-maritimdunia_54f97e43a3331178178b4f62 (diakses 10-03-2016). 
dan memberikan bagian yang ditentukan oleh raja kepada mereka (Safri Burhanuddin, dkk, 2003:72). Hal tersebut membuat para bajak laut menjadi bagian dari organisasi perdagangan kerajaan sekaligus pengaman jalur-jalur pelayaran. Selain itu, Sriwijaya juga menerapkan politik laut model paksaan menimbun barang yang mewajibkan kapal-kapal asing untuk singgah di pelabuhannya. Berbeda degan Majapahit, strategi pengamanan wilayah maritim Kerajaan Majapahit adalah dengan menjalankan tindakan tegas terhadap pemberontak (Safri Burhanuddin, dkk, 2003:88).

Sayangnya, dominasi penguasaan wilayah melalui perdagangan yang dilakukan oleh nenek moyang Bangsa Indonesia berakhir pada saat Panglima Pajang Senapati memberontak terhadap ahli waris sah Pajang, membubarkan, serta menelantarkan armada laut hingga membuat Jawa terisolir dari dunia luar (Irwan Djoko Nugroho, 2010:164). Hal tersebut membawa Jawa dan wilayah yang pernah disatukannya, Nusantara, Cina, Indocina, dan India dalam masa kegelapan karena menjauhkan Jawa dan wilayahnya dari pola pikir maritim dengan menakuti masyarakat yang akan melaut dan menetapkan politik kerajaan maritim sebelumnya sebagai penyakit yang harus dijauhi.

Jika Pemerintah dapat menggali lebih dalam potensi maritim, bukan hal yang mengherankan apabila kekuatan maritim Indonesia di masa yang akan datang lebih maju daripada kekuatan maritim di masa kerajaan Majapahit. ${ }^{3}$ Berdasarkan latar belakang tersebut, untuk mengembalikan kejayaan Nusantara, maka pengaturan terhadap wilayah Indonesia tidak boleh dilepaskan dari hakikat awalnya sebagai negara maritim yang berpulaupulau. Namun sayangnya, orientasi pembangunan Indonesia terlihat sangat bervisi kontinental bukan bervisi maritim, sebagai contoh, dalam Anggaran Pendapatan dan Belanja Negara di masa lalu (Orde Baru) maupun dalam rencana pembangunan berjangka saat ini, persentase pembangunan di bidang kelautan/ maritim masih jauh ketinggalan dari pembangunan di bidangbidang non-maritim lainnya. ${ }^{4}$

Oleh karena hukum merupakan wujud dari semangat jati diri suatu bangsa, maka untuk memahami hukum suatu bangsa, tidak dapat dilepaskan dari sejarah bangsa itu sendiri. Menurut mahzab sejarah hukum, hukum tidak diciptakan, tetapi ditemukan (Widodo Putro, 2017:14). Demikian juga untuk memahami pengaturan wilayah maritim yang ideal bagi NKRI, penting untuk memahami sejarah maritim para pendahulu Bangsa Indonesia yang hidup di zaman Kerajaan Sriwijaya dan Kerajaan Majapahit.

Penelitian ini bertujuan untuk menggali pengetahuan tentang bagaimana penguasaan Kerajaan Sriwijaya dan Kerajaan Majapahit terhadap wilayah

3) http://nasional.kompas.com/read/2014/10/09/22145401/Maksimalkan.Sisi.Maritim. Indonesia. Bisa.Lebih.Maju.dari.Majapahit.dan.Sriwijaya (diakses 11-03-2016).

4)http://jurnalmaritim.com/2014/11/strategi-maritim-untuk-pertahanan-indonesia/ (diakses 10-03-2016). 
maritimnya. Praktik pengaturan wilayah maritim pada masa kini tentu dapat mengambil praktik-praktik penguasaan wilayah maritim yang baik pada zaman Kerajaan Sriwijaya dan dan Kerajaan Majapahit. Itulah mengapa secara hukum penting untuk mengkaji apakah praktik pengaturan wilayah maritim pada zaman Kerajaan Sriwijaya dan Kerajaan Majapahit dipraktikkan dalam pengaturan wilayah maritim Negara Kesatuan Republik Indonesia kini.

Sesuai dengan permasalahan yang akan diteliti, penelitian ini merupakan penelitian hukum (legal research). Berdasarkan jenisnya, penelitian ini merupakan penelitian hukum normatif. Penelitian ini dapat digolongkan sebagai penelitian hukum normatif yang bersifat deskriptif analitis. Penelitian yang bersifat deskriptif analitis berusahan mengungkap peraturan perundangundangan yang berkaitan dengan teori-teori hukum yang menjadi objek penelitian (Zainuddin Ali, 2014:106).

Untuk mengkaji permasalahan dalam penelitian ini, diperlukan adanya pendekatan. Penelitian ini menggunakan pendekatan historis (historical approach). Pendekatan historis dilakukan dalam kerangka pelacakan sejarah lembaga hukum dari waktu ke waktu untuk memahami filosofi dari aturan hukum dari waktu ke waktu dan untuk memahami perubahan dan perkembangan filosofi yang melandasi aturan hukum tersebut (Peter Mahmud Marzuki, 2005:93).

\section{Penguasaan Kerajaan Sriwijaya dan Kerajaan Majapahit Terhadap Wilayah Maritimnya}

Kerajaan Sriwijaya merupakan suatu kerajaan pantai, sebuah negara perniagaan dan negara yang berkuasa di laut (Safri Burhanuddin, dkk, 2003:115). ${ }^{5}$ Kekuasaan Kerajaan Sriwijaya disebabkan oleh kebiasaan perdagangan internasional melalui Selat Malaka, sehingga berhubungan dengan jalur perdagangan internasional dari Asia Timur ke Asia Barat dan Eropa. Letak geografis Sriwijaya merupakan suatu modal yang baik untuk ikut serta dalam perdagangan internasional yang mulai berkembang antara India dan daratan Asia Tenggara.

Sebagai kerajaan maritim yang hidup berdasarkan sektor perdagangan dan pelayaran, penguasa Sriwijaya menguasai jalur-jalur perdagangan dan pelabuhan melalui kebiasaan menimbun barang untuk diperdagangkan. Dalam perkembangannya, kebiasaan menimbun barang itu menjadi hukum adat yang

5) Penguasa pesisir tertarik untuk melakukan perdagangan karena beberapa alasan, antara lain (1) mendapatkan pemasukan dari dunia perniagaan; (2) penguasa yang tergantung pada surprlus agraris terancam dengan uang tunai dan peralatan militer yang mana dapat dipenuhi melalui kehidupan perniagaan; (3) dengan ikut andil dalam dalam perdagangan, penguasa ikut andil dalam pengembangan pasar yang akan meningkatkan pendapatan mereka; (4) dunia perniagaan memungkinkan penguasa untuk mendapatkan komoditas prestigious yang sangat penting untuk meligitimasi kekuasaan dan kewibawaannya, seperti mengoleksi barang impor yang mewah. 
disebut sebagai "paksaan menimbun barang" (Soerjono Soekanto, dalam C. Dewi Wulansari, 2012:10). ${ }^{6}$ Sriwijaya menggunakan "paksaan menimbun barang” untuk mewajibkan kapal-kapal singgah di pelabuhannya (C. Dewi Wulansari, 2012:63). Dengan singgahnya kapal-kapal di pelabuhan Sriwijaya, Raja Kerajaan Sriwijaya dapat memungut bea dari perdagangan yang melalui wilayah maritim Sriwijaya (Marwati Djoened Poesponegoro dan Marwati Djoened, 1984: 60-61).

Selain sebagai penguasa, Raja Sriwijaya dan para bangsawan juga melakukan perdagangan sendiri. Melalui perdagangan dan hukum adat yang berlaku, Raja dapat menguasai wilayah maritim dan menimbun kekayaan. Raja Sriwijaya bahkan mempunyai kapal-kapal sendiri. Selain itu, kekayaan raja dan para bangsawan juga diperoleh dari rampasan hasil peperangan dan pembajakan laut (Marwati Djoened Poesponegoro dan Marwati Djoened, 1984:60-61). Untuk mengamankan wilayah Sriwijaya dari bajak laut, Pemerintah Sriwijaya mengeluarkan kebijakan memasukkan kepala bajak laut dalam ikatan kerajaan, sehingga mereka menjadi bagian dari organisasi perdagangan kerajaan sekaligus menjadi pengaman bagi jalur-jalur pelayaran (Safri Burhanuddin, dkk, 2003:72).

Sebagaimana hukum adat yang berlaku pada masa itu, pemimpinpemimpin yang negaranya takluk di bawah pemerintahan Sriwijaya, selain menyatakan diri sebagai bagian dari naungan Sriwijaya, mempunyai pemerintahan sendiri (O.W. Wolters, 1970:293). Dengan meluasnya wilayah Sriwijaya, hukum adat "paksaan menimbun barang" juga memiliki cakupan yang lebih luas karena Raja Sriwijaya mewajibkan kapal lokal dan asing yang lewat pada daerah-daerah taklukannya baik dari Cina maupun menuju ke Cina untuk singgah di pelabuhan Sriwijaya (O.W. Wolters, 1970:293). ${ }^{7}$

Untuk melanggengkan kekuasaannya, Kerajaan Sriwijaya menjalin hubungan diplomasi dengan negeri-negeri adidaya lain di sekitarnya. Melalui hubungan diplomasi tersebut, kekuasaan Sriwijaya terhadap wilayahnya mendapat pengakuan dari kerajaan lain dan juga mendapatkan dukungan jika ada penyerangan terhadap kerajaan tersebut. Selain melalui hubungan diplomasi, pengembangan kekuasaan Sriwijaya dilakukan melalui penguasaan terhadap simpul-simpul perdagangan dan arus perdagangan yang ada dengan berbagai cara, seperti pelayaran dan ekspedisi militer.

Pada sekitar tahun 1325 Masehi, peranan Sriwijaya sebagai suatu kerajaan internasional berakhir karena ditaklukkan oleh kerajaan Jawa. Saat riwayat Kerajaan Sriwijaya yang sempat berjaya selama 7 abad berakhir, pada sekitar tahun 1300 Masehi, munculah Kerajaan Majapahit. Keistimewaan

6) Soerjono Soekanto berpendapat bahwa tidak ada perbedaan yang berarti antara hukum adat dan hukum kebiasaan karena hukum adat pada hakikatnya merupakan hukum kebiasaan, artinya kebiasaan-kebiasaan yang mempunyai akibat hukum (sein-sollen).

7) Beberapa pelabuhan dianggap mulai berkembang dan bersaing, sehingga perdagangan juga dibatasi hanya untuk mengirim hasil bumi ke Palembang. 
Kerajaan Majapahit adalah pada kemampuannya menyinergikan tradisi pelayaran-perniagaan sungai dan tradisi agraris dengan potensi kemaritiman yang telah dikuasainya melalui tradisi kemaritiman Kediri (Djoko Suryo dan Darmanto [Peny.], 2014:8-12). ${ }^{8}$

Kerajaan Majapahit menguasai wilayahnya melalui kebiasaan ekspansi yang mengedepankan cara-cara persuasif. Apabila cara-cara yang bersifat persuasif tidak berhasil, maka kekuatan militer digunakan (Irawan Djoko Nugroho, 2011:20). ${ }^{9}$ Kebiasaan tersebut melahirkan hukum adat penguasaan wilayah yang memberikan kebebasan pada daerah taklukan untuk mengatur urusan rumah tangganya sendiri, sekaligus pada waktu tertentu menunjukkan kepatuhan pada Pemerintah Pusat Majapahit.

Jika suatu daerah takluk di bawah kekuasaan Majapahit, maka pada umumnya Pemerintah Majapahit tidak mencampuri urusan internal daerah tersebut (R. Soekmono, 2002:40-41). ${ }^{10}$ Majapahit hanya mewajibkan daerah bawahannya untuk menyampaikan upeti atau uang takluk, mengirimkan utusan pada waktu-waktu tertentu sebagai tanda takluk di bawah penguasaan Majapahit, dan dalam pengambilan keputusan sesuai dengan kehendak Pemerintah Majapahit bagi wilayah kekuasaannya (Megandaru W. Kawuryan, 2006: 185-187). ${ }^{11}$ Bagi daerah-daerah yang jauh dari pusat kekuasaan Majapahit,

8) Tercatat sebagai bandar cukup vital pada masa itu adalah Bandar Tjanggu di Sungai Brantas dan Bandar Sedayu di Bengawan Solo. Untuk melindungi perdagangannya dibangun Bandar Militer Tuban di Pulau Jawa dan Bandar Militer Bangkalan di Madura.

9) Dengan mengedepankan pendekatan "kekeluargaan", militer menjadi pilihan terakhir bila cara-cara lain tidak berhasil, sehingga kerajaan-kerajaan di zona Laut Jawa memiliki ikatan lain, selain penjajahan. Kisah yang bisa dijadikan bukti penyataan ini terdapat pada kisah sebagaimana yang tercatat dalam Sejarah melayu. Dalam cerita tersebut, Raja Majapahit menegur Raja Singapura karena lancang tidak menyembah kepada Raja Majapahit. Padahal Kerajaan Singapura kecil dan angkatan lautnya tidak sekuat Majapahit. Raja Singapura diminta berinteropeksi bahwa kekuatannya tidak seberapa dan diminta untuk kembali menyembah Majapahit. Raja Singapura marah dan menaruh rambut seorang budak di depan utusan dari Jawa. Raja Majapahit pun murka menerima tarahan rambut budak itu, kemudian barulah Raja Majapahit mengirim pasukannya untuk menaklukan Singapura dengan senjata.

10) Salah satunya dibuktikan dengan Kerajaan Samudera di Aceh yang beragama Islam dan menjadi bagian dari Majapahit serta berhubungan secara langsung dengan Tiongkok, ternyata tidak dipermasalahkan oleh Majapahit. Bahkan, ketika seorang Raja dari Samuder melarikan diri meninggalkan tahkta, ia berlari ke Majapahit dan hal itu tidak menjadi suatu hal yang ganjil.

11) Kewajiban utama daerah bawahan terhadap pusat adalah menyerahkan upeti tahunan dan menghadap raja Majapahit pada waktu-waktu yang ditetapkan sebagai tanda kesetiaan dan pengakuan kekuasaan Majapahit. Pemerintah pusat tidak mencampuri urusan daerah. Negara di seberang lautan tidak mengalami perubahan apapun setelah menjadi daerah bawahan Majapahit. Untuk urusan negara raja-raja atau pembesar daerah bawahan di seberang lautan berdaulat penuh. Majapahit memelihara angkatan laut yang sangat besar untuk melindungi daerah-daerah bawahan dan menghukum pembesar daerah yang membangkan terhadap pusat pemerintahan. Konon angkatan laut Majapahit telah banyak berjasa, terutama dalam merebut kekuasaan di daerah sebrang lautan dan membinasakan musuh-musuh yang melawan kekuasaan Majapahit. Pengertian daerah bawahan pada abad ke-14 berbeda dengan pengertian koloni dalam zaman modern. Persembahan upeti yang tidak banyak nilainya, oleh 
kekuasaan Majapahit dijadikan sebagai pengaruh bagi daerah tersebut.

Majapahit bersikap terbuka pada daerah kekuasaannya, namun juga sekaligus bersikap tegas. Jika ada pegawai Majapahit, seperti wali negeri, adipati, atau menteri dikirim ke daerah yang ditaklukkan, hal tersebut dimaksudkan untuk mempertegas kekuasaan Majapahit serta untuk memungut sumbangan dari daerah itu. Majapahit juga memiliki sikap yang keras terhadap pengaruh asing. Sikap keras Majapahit ini dibuktikan dengan kuatnya angkatan laut dan angkatan darat kerajaan untuk melakukan ekspedisi, pengawasan, dan bertindak terhadap negara asing yang hendak mencampuri keadaan dalam negeri Kerajaan Majapahit (Megandaru W. Kawuryan, 2006:188). ${ }^{12}$

Dalam menjamin keamanan di wilayahnya, ketika bagian Barat Kalimantan pada tahun 1369 Masehi dikacaukan oleh bajak laut dari Sulu, Filipina, yang dibantu oleh Tiongkok, segera armada Majapahit muncul di lautan Tiongkok Selatan, sehingga daerah tersebut terhindar dari pengacau (Safri Burhanuddin, dkk, 2003:88). Pada tahun 1370 Masehi, tiga orang raja di Nusantara berusaha melepaskan diri dari Majapahit dan mengirimkan utusan sendiri ke Tiongkok, akibatnya Majapahit mengirimkan armada dan pada tahun 1377 raja-raja tersebut dibinasakan (Safri Burhanuddin, dkk, 2003:88).

Efektivitas penguasaan Majapahit terhadap wilayah maritimnya tidak dapat dilepaskan dari duo kepemimpinan raja dan patihnya, Raja Hayam Wuruk dan Patih Gadjah Mada. Pada saat kepemimpinan Hayam Wuruk, kepastian hukum menjadi pilar yang penting dalam kehidupan kerajaan. Hal tersebut dibuktikan dengan dituliskannya kitab undang-undang Negarakertagama yang mengatur tentang kehidupan kerajaan Majapahit dan untuk menjaga wibawa kerajaan, Majapahit membentuk pengadilan bernama Saptopati. ${ }^{13}$ Negarakertagama merupakan hukum tertulis Kerajaan Majapahit yang mengatur jalannya roda pemerintahan negara dan kehidupan rakyat Majapahit.

Gadjah Mada mengeluarkan karya yang menyangkut hukum adat antara lain ketika ia menjadi Bekel Bhayangkara para pemuda dibagi dalam dua golongan, yaitu darmaputera dan bhayangkara. Darmaputera adalah golongan pemuda yang bertugas sebagai penjaga pusat kedudukan pemerintahan dan mahkota, sedangkan bhayangkara adalah golongan pemuda yang bertugas sebagai penjaga keamanan dan kehormatan negara (Muhammad Yamin dalam

daerah tertentu kepada Majapahit, sudah dapat dianggap sebagai bukti pengakuan kekuasaan Majapahit atas daerah yang bersangkutan dan karenanya daerah itu dianggap sebagai bawahan. Sebagai contoh misalnya daerah Purni (Brunei) yang hanya mempersembahkan upeti tahunan berupa kapur barus sebanyak empat puluh kati kepada raja Majapahit.

12) Pembinaan angkatan laut yang besar merupakan syarat mutlak bagi Majapahit sebagai negara Maritim untuk mempertahankan kekuasaannya dilaut teduh (pasifik); sebagian ditempatkan dipantai utara Jawa untuk melindungi negara induk, sebagian disebar dibeberapa tempat untuk mengawasi daerah bawahan.

13) http://www.kompasiana.com/pagar_sianipar/singasari-dan-majapahit_54f3de83 745513932b6c81f8 (diakses 0-09- 2016). 
Hilman Hadikusuma, 1978: 25-26). ${ }^{14}$ Ketika menjabat sebagai Mangkubumi pada masa Raja Hayam Wuruk, tugas kenegaraan diatur dalam beberapa instansi sebagai berikut:

Sang Prabu adalah ketua sidang mahkota yang mengurus urusan rumah tangga keraton dan anggota keluarga Prabu, mengatur soal perkawinan, peralihan mahkota, kedudukan mahkota, dan ketentaraan negara;

Sang Prabu memerintahkan negara dengan empat badan pemerintahan yang terdiri dari Mantri Katrini atau Maha Meteri yang tiga, yaitu Manteri Hino, Manteri Sirikan, dan Manteri Halu; Panca Ring Wilwatikta adalah lima serangkai Majapahit yang merupakan departemen-departemen yang terdiri dari empat rakyan dan seorang mahapatih. Bidang pemerintahan umum dipimpin oleh Gadjah Mada dan yang menyangkut politik negara dibicarakan dan dilaksanakan oleh Panca Ring Wilwatikta dan Mantri Katrini; Dharmajaksa adalah jabatan keagamaan yang terdiri dari Kepala Agama Budha dan Kepala Agama Syiwa; dan Sapta papatti atau upapatti terdiri dari Pamegat Agama Syiwa dan dua petugas Agama Budha yang disebut Kandangan Atuha dan Kandangan Rare. Urusan mereka adalah mengenai soal agama dan kerohanian (Muhammad Yamin dalam Hilman Hadikusuma, 1978: 25-26).

Penguasaan Majapahit terhadap wilayah maritimnya tidak dapat dilepaskan dari sistem pemerintahannya baik secara formal maupun secara informal. Secara formal sistem pemerintahan Kerajaan Majapahit dapat dibedakan dalam pegawai resmi kerajaan (royal official) dan bangsawan dengan gelar rakai, rakryan dan pamegat (landed nobility with titles such as rakai, rakryan, and pamegat) (J.G. de Casparis dalam David G. Marr and A.C. Miller [Peny.], 1990:51). Secara informal, hubungan antarsatuan pemerintahan dilakukan melalui pemungut pajak lain-lain (miscellaneous tax collectors known as those "who claim the king's property/ manilala drawya haji); penguasa keagamaan yang melekat ada candi, biara, pertapaan, dan yang serupa (religious authorities attached to temples, monasteries, hermitages, and similar institutions); dan hubungan lansung antara warga desa, tetua desa, dan raja atau perwakilannya (direct contacts between villagers, in particular village elders, and the king or his direct subordinates) (J.G. de Casparis dalam David G. Marr and A.C. Miller [Peny.], 1990:51-52).

Raja Majapahit sering melakukan kunjungan langsung untuk melihat keadaan rakyatnya. Pada saat kunjungan tersebut, raja tidak hanya secara langsung memperlihatkan dirinya kepada masyarakat, namun masyarakat juga dapat secara langsung berinteraksi dengan raja. Pada kesempatan ini, dimungkinkan adanya pengawasan terhadap perwakilan raja di daerah. Dalam

14) Pemerintahan Majapahit dijalankan atas dasar musyawarah dan mufakat yang dipimpin langsung oleh Gadjah Mada atau anggota sidang Saptoprabu. Kedudukan hakim langsung di bawah Sang Prabu dan di dalam memutus perkara didasarkan pada hukum adat setempat dengan mengindahkan hukum adat yang tertulis dari negara. 
kesempatan tertentu, rakyat juga dapat menyampaikan petisi kepada raja.

Penguasaan Kerajaan Sriwijaya dan Kerajaan Majapahit terhadap wilayah maritimnya bukan hanya disebabkan oleh kegiatan perdagangan berdasarkan letak geografis yang strategis, namun juga disebabkan oleh penguasaan industri. Bahwa permintaan pasar Asia dan dunia terhadap produk Indonesia bukan hanya terhadap hasil tanaman tropis, tetapi juga terhadap produk industri, seperti alat logam untuk peralatan rumah tangga, pertanian, persenjataan, dan pertukangan; serta produksi tekstil berupa kain tradisional dan perhiasan emas maupun perak. Permintaan produksi industri tersebut dapat dipenuhi oleh kedua kerajaan, sehingga banyak kapal-kapal asing yang singgah di bumi Nusantara untuk melakukan perdagangan.

Sebagai kerajaan maritim, angkatan laut yang kuat adalah prasyarat wajib untuk menjamin stabilitas dan kelangsungan suatu kerajaan. Baik Sriwijaya maupun Majapahit, sama-sama mempunyai angkatan laut yang kuat untuk mempertahankan penguasaan kedua kerajaan tersebut terhadap wilayah maritimnya. Dalam struktur pemerintahan Sriwijaya, Laksamana Angkatan Laut kerajaan sebagai jabatan kemiliteran yang sangat penting berada langsung di bawah raja penguasa tertinggi dan sejajar dengan patih (mangkubumi) dengan tugas utama menjaga keutuhan wilayah dan menjaga kepentingan Sriwijaya di bidang perdagangan (Soeroso M.P. Achadiati S, 1988: 15-16).

Kekuatan armada Kerajaan Majapahit ditegaskan dalan Negarakertagama bahwa Majapahit memiliki angkatan laut yang sangat besar untuk melindungi daerah bawahan dan untuk menghukum pembesar daerah yang membangkang terhadap pemerintahan (Irawan Djoko Nugroho, 2011:16) ${ }^{15}$ Armada Jawa adalah kekuatan terbesar armada gugus kapal perang Majapahit karena tugasnya paling berat menjaga pusat kerajaan istana Majapahit. ${ }^{16}$ Angkatan laut ini ditempatkan di pantai utawa jawa untuk melindungi negara induk, sebagian disebar untuk mengawasi daerah bawahan, dan digunakan untuk mengawal petugas yang memunguti upeti di daerah supaya keamanannya terjamin dan berjalan lancar (Slamet Mulyana, 1979:148). Untuk mendukung armadanya, Kerajaan Majapahit mempunyai industri perkapalan yang handal.

15) Menurut Sejarah Melayu dan Hikayat Raja-Raja Pasai serta informasi Arab, jumlah perahu yang dimiliki negara-negara di Asia dalam satu ekspedisi umumnya sebanyak 100 buah. Banyaknya armada kapal menunjukan kuatnya kerajaan yang dimilikinya. Armada yang memiliki jumlah kapal diatas rata-rata adalah Makassar dan Jawa. Makassar memiliki 200 perahu dalam satu ekspedisi. Sedangkan Jawa memiliki lebih dari 2.800 perahu dalam satu ekspedisi. Banyaknya armada laut dalam satu ekspedisi dan dalam satu wilayah menunjukan bahwa kerajaan tersebut lebih tangguh dibanding kerajaan lain dimasanya. Dengan demikian armada laut tertangguh pada masa itu adalah Jawa yang merupakan negara maritim utama.

16) Armada itu sekaligus menguasai jalur laut menuju kepulauan rempah-rempah Maluku yang dikuasai langsung pemerintah pusat Majapahit. http://nasional.news.viva. co.id/news/read/637865-kerajaan-majapahit-dijaga-lima-gugus-kapal-perang (diakses 0209-2016). 
Setiap kapal perang Majapahit bersenjatakan meriam Jawa yang disebut cetbang Majapahit dan pandai besi yang mengecor meriam itu berada di Blambangan. ${ }^{17}$

\section{Penguasaan Wilayah Maritim Negara Kesatuan Republik Indonesia Kini}

Salah satu unsur negara adalah wilayah (Miriam Budiarjo, 1981:41). Soekarno mengatakan bahwa tiga kali kita mempunyai negara kesatuan yang wilayahnya meliputi seluruh nusantara Indonesia, yaitu Sriwijaya, Majapahit, dan Republik Indonesia (Cahyo Gumilang, dkk [Peny.], 2013: 125). Menurut Soekarno, Republik Indonesia akan tetap berdiri kekal dan tidak runtuh sebagaimana Sriwijaya dan Majapahit apabila Indonesia berdiri berdasarkan Pancasila (Cahyo Gumilang, dkk [Peny.], 2013: 125). Salah satu prinsip penting dalam Pancasila adalah Persatuan Indonesia.

Persatuan Indonesia merupakan suatu perwujudan dalam bentuk yang dinamis karena sifat kesatuannya harus selalu dipelihara (Kaelan, 2013:273274). Pada realitasnya, Negara Indonesia adalah negara kepulauan dimana laut yang berada diantara pulau-pulau menjadi jembatan penghubung, bukan pemisah, sehingga penguasaan laut menjadi suatu keharusan bagi para penduduk yang mengusai pulau-pulau tersebut. Untuk mewujudkan Persatuan Indonesia, pada Desember 1957 dikeluarkanlah Deklarasi Juanda. Melalui Deklarasi Juanda, Pemerintah Indonesia menyatakan bahwa bentuk grografi Indonesia sebagai suatu negara kepulauan mempunyai corak tersendiri dan menurut sejarah sejak dahulu kala Kepulauan Indonesia merupakan suatu kesatuan, sehingga batas laut teritorial yang termaktub dalam Territoriale Zee en Maritieme Kroningen Ordonnantie 1939 memecah keutuhan wilayah Indonesia karena membagi wilayah daratan Indonesia dalam bagian-bagian terpisah dengan wilayah lautnya (D. Negarayati Siregar [Peny.], 2001:90).

Deklarasi Juanda kemudian diatur dalam Peraturan Pemerintah Pengganti Undang-Undang Nomor 4 Tahun 1960 tentang Perairan Indonesia (Perpu 4/1960). Perpu 4/1960 menegaskan bahwa kepulauan Indonesia merupakan satu kesatuan (unit) dan bahwa lautan diantara pulau-pulau Indonesia merupakan bagian yang tak dapat dipisahkan dari bagian darat (pulau-pulau) Negara Indonesia. Meskipun demikian, Pemerintah Indonesia tetap menjamin lalu lintas damai di lautan pedalaman bagi kapal asing selama tidak membahayakan kedaulatan dan keselamatan negara Indonesia. ${ }^{18}$

NKRI dibagi atas daerah-daerah provinsi dan daerah provinsi dibagi atas kabupaten dan kota, yang tiap-tiap provinsi, kabupaten, dan kota

17) Cetbang Majapahit adalah karya penemuan Mahapatih Gajahmada yang konon pernah diasuh tentara Mongol atau Tartar yang menyerang kerajaan Singosari dengan kekuatan 1.000 kapal. http://nasional.news.viva.co.id/news/read/637865-kerajaanmajapahit-dijaga-lima-gugus-kapal-perang (diakses 02-09- 2016).

18) Penjelasan Umum Perpu 4/1960. 
itu mempunyai pemerintahan daerah. ${ }^{19}$ Pemerintah daerah menjalankan otonomi seluas-luasnya, kecuali urusan pemerintahan yang oleh undangundang ditentukan sebagai urusan Pemerintah Pusat. ${ }^{20}$ Otonomi daerah lahir berdasarkan desentralisasi kekuasaan dari Pemerintah Pusat ke Pemerintahan Daerah. Praktik desentralisasi sebagai upaya penguasaan wilayah maritim di Indonesia, telah dikenal sejak zaman Kerajaan Sriwijaya dan Kerajaan Majapahit. Meskipun pada waktu itu tidak disebut sebagai desentralisasi, baik kerajaan Sriwijaya maupun Kerajaan Majapahit memberikan keluasaan kepada daerah bawahannya untuk mengatur dan mengurus sendiri urusan pemerintahannya, kecuali urusan-urusan yang ditentukan lain oleh Pemerintah Pusat atau oleh kedua kerajaan tersebut. Saat ini, berdasarkan Pasal 1 angka 8 Undang-Undang Nomor 23 Tahun 2014 tentang Pemerintahan Daerah (UU 23/2014), desentralisasi adalah penyerahan urusan pemerintahan oleh pemerintah pusat kepada daerah otonom berdasarkan asas otonomi. ${ }^{21}$ Melalui desentralisasi, daerah mempunyai kewenangan untuk mengurus dan mengatur urusan pemerintahan di daerah tersebut.

Berdasarkan UU 23/2014, kelautan dan perikanan merupakan urusan pemerintahan pilihan, yaitu urusan pemerintahan yang wajib diselenggarakan oleh daerah sesuai dengan potensi yang dimiliki daerah. Urusan bidang kelautan dan perikanan dibagi menjadi beberapa sub-urusan, yaitu kelautan, pesisir, dan pulau-pulau kecil; perikanan tangkap; perikanan budidaya; pengawasan sumber daya kelautan dan perikanan; pengolahan dan pemasaran; karantina ikan, pengendalian mutu dan keamanan hasil perikanan; serta pengembangan Sumber Daya Manusia Masyarakat Kelautan dan Perikanan. Kewenangan pelaksanaan sub sub-bidang tersebut, beberapa diantaranya dibagi antara pemerintah pusat, daerah provinsi, dan daerah kabupaten/kota.

Sebagaimana telah diketahui bahwa Republik Indonesia merupakan negara kepulauan, Negara Indonesia mengakui adanya daerah provinsi yang berciri kepulauan. Berdasarkan Pasal 28 ayat (1) UU 23/2014, daerah provinsi yang Berciri Kepulauan mempunyai kewenangan mengelola sumber daya alam di laut yang meliputi (a) eksplorasi, eksploitasi, konservasi, dan pengelolaan kekayaan laut di luar minyak dan gas bumi; (b) pengaturan administratif; (c) pengaturan tata ruang; (d) ikut serta dalam memelihara keamanan di laut; dan (e) ikut serta dalam mempertahankan kedaulatan negara. Selain mempunyai kewenangan tersebut, daerah provinsi yang berciri kepulauan mendapat penugasan dari Pemerintah Pusat untuk melaksanakan kewenangan

19) Pasal 18 Ayat (1) Undang-Undang Dasar Negara Republik Indonesia Tahun 1945.

20) Pasal 18 Ayat (5) Undang-Undang Dasar Negara Republik Indonesia Tahun 1945.

21) UU 23/2014 telah diubah dua kali dengan Undang-Undang Nomor 2 Tahun 2015 tentang Penetapan Peraturan Pemerintah Pengganti Undang-Undang Nomor 2 Tahun 2014 tentang Perubahan atas Undang-Undang Nomor 23 Tahun 2014 tentang Pemerintahan Daerah Menjadi Undang-Undang dan Undang-Undang Nomor 9 Tahun 2015 tentang Perubahan Kedua atas Undang-Undang Nomor 23 Tahun 2014 tentang Pemerintahan Daerah. 
Pemerintah Pusat di bidang kelautan berdasarkan asas tugas pembantuan yang dilaksanakan berdasarkan norma, standar, prosedur, dan kriteria yang ditetapkan oleh Pemerintah Pusat.

Kawasan perairan Indonesia merupakan suatu sistem network yang tediri dari beberapa sub-network dari aktivitas perdagangan, politik, kebudayaan, dan sebagainya (Safri Burhanuddin, dkk, 2003:13). Bukan hanya Kerajaan Sriwijaya dan Kerajaan Majapahit yang secara khusus memberikan perhatian terhadap kawasan strategis perdagangan, tetapi juga Republik Indonesia memperhatikan kawasan tersebut dengan penetapan kawasan strategis bagi kepentingan nasional, antara lain kawasan perdagangan bebas dan/ atau pelabuhan bebas; kawasan ekonomi khusus; kawasan angkatan perang; kawasan otorita; kawasan bandara; kawasan pelabuhan; dan kawasan sepanjang rel kereta api. ${ }^{22}$

Kawasan perdagangan bebas dan/atau pelabuhan bebas ditetapkan berdasarkan pertimbangan bahwa antara lain suatu daerah perdagangan dan pelabuhan bebas dapat mendorong kegiatan lalu lintas perdagangan internasional yang mendatangkan devisa bagi negara serta dapat memberi pengaruh dan manfaat besar bagi Indonesia, untuk dapat membuka lapangan kerja seluas-luasnya, meningkatkan kepariwisataan dan penanaman modal baik asing maupun dalam negeri. ${ }^{23}$ Di dalam wilayah NKRI, terdapat beberapa kawasan perdagangan bebas dan pelabuhan bebas, yaitu Sabang, Batam, Karimun, Bintan, dan Bandar Udara Hang Nadim Batam. ${ }^{24}$

Kawasan Perdagangan Bebas dan Pelabuhan Bebas adalah suatu kawasan yang berada dalam wilayah hukum NKRI yang terpisah dari daerah pabean sehingga bebas dari pengenaan bea masuk, pajak pertambahan nilai, pajak penjualan atas barang mewah, dan cukai. ${ }^{25}$ Kawasan Perdagangan Bebas dan Pelabuhan Bebas mempunyai fungsi sebagai tempat untuk mengembangkan usaha-usaha di bidang perdagangan, jasa, industri, pertambangan dan energi, transportasi, maritim dan perikanan, pos dan telekomunikasi, perbankan, asuransi, pariwisata dan bidang-bidang lainnya. ${ }^{26}$

22) Pasal 360 ayat (1) dan (2) UU 23/2014.

23) Bagian Menimbang Peraturan Pemerintah Pengganti Undang-Undang Nomor 1 Tahun 2000 tentang Kawasan Perdagangan Bebas dan Pelabuhan Bebas (Perpu 1/2000).

24) Peraturan Pemerintah Pengganti Undang-Undang Nomor 2 Tahun 2000 tentang Kawasan Perdagangan Bebas dan Pelabuhan Bebas Sabang; Peraturan Pemerintah Republik Indonesia Nomor 46 Tahun 2007 tentang Kawasan Perdagangan Bebas dan Pelabuhan Bebas Batam; Peraturan Pemerintah Republik Indonesia Nomor 47 Tahun 2007 tentang Kawasan Perdagangan Bebas dan Pelabuhan Bebas Bintan; Peraturan Pemerintah Republik Indonesia Nomor 48 Tahun 2007 tentang Kawasan Perdagangan Bebas dan Pelabuhan Bebas Karimun; dan Peraturan Pemerintah Republik Indonesia Nomor 65 Tahun 2014 tentang Penyelenggaraan Kegiatan di Bandar Udara Hang Nadim Batam oleh Badan Pengusahaan Kawasan Perdagangan Bebas Dan Pelabuhan Bebas Batam.

25) Pasal 1 angka 1 Perpu 1/2000.

26) Pasal 9 ayat (1) Perpu $1 / 2000$. 
Pelayaran merupakan urusan pemerintahan yang penting dalam sejarah Kerajaan Sriwijaya dan Majapahit karena pelayaran merupakan kegiatan yang menghubungkan antarwilayah kerajaan. Saat ini, di Negara Indonesia alat penghubung antarwilayah bukan hanya melalui pelayaran, namun juga termasuk lalu lintas dan angkutan jalan; penerbangan; dan perkeretaapian. Di Indonesia, kewenangan pengaturan administrasi antara lain perizinan, kelaikan, dan keselamatan pelayaran ada pada daerah provinsi. ${ }^{27}$

Pada zaman Kerajaan Sriwijaya dan Kerajaan Majapahit, kekuatan militer menjadi salah satu faktor yang penting dalam upaya pertahanan keamanan dan kedaulatan kerajaan. Demikian juga dengan Republik Indonesia saat ini, Tentara Nasional Indonesia dan Kepolisian Negara Republik Indonesia merupakan kekuatan utama dalam usaha pertahanan dan keamanan negara. Tentara Nasional Indonesia terdiri atas Angkatan Darat, Angkatan laut dan Angkatan Udara sebagai alat negara bertugas mempertahankan, melindungi, dan memelihara keutuhan dan kedaulatan negara, sedangkan Kepolisian Negara Republik Indonesia sebagai alat negara yang menjaga keamanan dan ketertiban masyarakat bertugas melindungi, mengayomi, melayani masyarakat, serta menegakkan hukum. ${ }^{28}$ Bahkan, Pasal 30 ayat (1) Undang-Undang Dasar Negara Republik Indonesia Tahun 1945 mengatur bahwa tiap warga negara berhak dan wajib ikut serta dalam usaha pertahanan dan keamanan negara.

Pada zaman Kerajaan Sriwijaya dan Majapahit, keunggulan armada laut kedua kerajaan tersebut bukan hanya pada kualitas sumber daya manusianya, namun juga dalam pengadaan alat utama sistem pertahanan. Meskipun kini Indonesia belum mampu memproduksi alat utama sistem pertahanan secara mandiri, hubungan internasional dapat membantu menjawab kebutuhan tersebut. Sebagai contoh Indonesia sudah menandatangani kerjasama dengan Korea Selatan dalam pembangunan pesawat tempur generasi 4,5 KFX/IFX (Korean-Indonesian Fighter Xperimental), Boramae, yang dalam rencana awalnya Angkatan Udara Tentara Nasional Indonesia akan memiliki sebanyak 50 buah pada tahun $2020 .{ }^{29}$ Selain itu, untuk mempertahankan penguasaan terhadap wilayah maritimnya, Angkatan Laut Tentara Nasional Indonesia mengintensifkan patroli pengamanan perbatasan maritim Indonesia dengan sejumlah negara lain, secara rutin terutama di 12 titik yang dianggap rawan, seperti perbatasan Republik Indonesia-Malaysia dan Republik IndonesiaSingapura. ${ }^{30}$

27) Pasal 27 UU 23/2014.

28) Pasal 30 ayat (3) dan (4) Undang-Undang Dasar Negara Republik Indonesia Tahun 1945.

29)http://forum.viva.co.id/indeks/threads/lomba-thread-puluhan-jutarupiah.2226108/s://tni-au.mil.id/pustaka/australia-makin-gundah-dengan-modernisasialutsista-tni-au (diakses 02-09-2016).

30)http://nasional.news.viva.co.id/news/read/102593-tni-al-jaga-12-titik-rawan-diperbatasan (diakses 02-09-2016). 
Kemasyuran Kerajaan Majapahit tidak dapat dilepaskan dari visi-misi Patih Gadjah Mada terhadap persatuan Kerajaan Majapahit yang dituangkan dalam Sumpah Palapa. Di Indonesia saat ini, agenda pembangunan nasional untuk mencapai kesejahteraan sosial bagi seluruh rakyat Indonesia tidak dapat dipisahkan dari visi-misi Presiden, Joko Widodo, yang dituangkan dalam Peraturan Presiden Republik Indonesia Nomor 2 Tahun 2015 tentang Rencana Pembangunan Jangka Menengah Nasional Tahun 2015-2019.

Agenda pembangunan nasional untuk menghadirkan kembali negara yang dapat melindungi segenap bangsa dan memberikan rasa aman pada seluruh warga negara adalah dengan memperkuat jatidiri sebagai negara maritim. Salah satu upaya untuk mewujudkan kemandirian ekonomi dengan menggerakkan sektor-sektor strategis ekonomi domestik adalah dengan pengembangan ekonomi maritim dan kelautan. Pembangunan karakter dan kegotongroyongan yang berdasar pada realitas kebhinekaan dan kemaritiman sebagai kekuatan potensi bangsa dalam mewujudkan implementasi demokrasi politik dan demokrasi ekonomi Indonesia masa depan merupakan penjabaran dari TRISAKTI. ${ }^{31}$

Selain dikuasai oleh Negara, wilayah maritim Indonesia juga dikuasai oleh Masyarakat Hukum Adat, seperti Kabupaten Halmahera Selatan di Provinsi Maluku Utara yang merupakan salah satu kabupaten berciri kepulauan di Republik Indonesia. Di kepulauan Halmahera Utara, hukum yang berlaku adalah hukum negara sebagaimana disebutkan di atas dan hukum adat. Masyarakat pesisir Halmahera Selatan menguasai laut di wilayah Kabupaten Halmahera Selatan dengan mempraktikkan hukum adat melalui tradisi kultural masyarakat di daerah pesisir dalam pengelolaan dan pemanfaatan wilayah laut, seperti pembayaran boboso ikan dan ngasi laut (Daud Djubedi, 2014:58).

Boboso merupakan konsep larangan untuk memakan, mengambil, atau melakukan sesuatu yang dilarang dalam ketentuan adat, misalnya pada saat Suku Bacan melakukan upacara sembelih kepala sapi saat musim paceklik,

31) Penjabaran TRISAKTI diwujudkan dalam bentuk: (1) Kedaulatan dalam politik diwujudkan dalam pembangunan demokrasi politik yang berdasarkan hikmat kebijaksanaan dalam permusyawaratan perwakilan. Kedaulatan rakyat menjadi karakter, nilai, dan semangat yang dibangun melalui gotong royong dan persatuan bangsa; (2) Berdikari dalam ekonomi diwujudkan dalam pembangunan demokrasi ekonomi yang menempatkan rakyat sebagai pemegang kedaulatan dalam pengelolaan keuangan negara dan pelaku utama dalam pembentukan produksi dan distribusi nasional. Negara memiliki karakter kebijakan dan kewibawaan pemimpin yang kuat dan berdaulat dalam mengambil keputu-san-keputusan ekonomi rakyat melalui penggunaan sumber daya ekonomi nasional dan anggaran negara untuk memenuhi hak dasar warga negara; (3) Kepribadian dalam kebudayaan diwujudkan melalui pembangunan karakter dan kegotongroyongan yang berdasar pada realitas kebhinekaan dan kemaritiman sebagai kekuatan potensi bangsa dalam mewujudkan implementasi demokrasi politik dan demokrasi ekonomi Indonesia masa depan. Lihat Buku I Agenda Pembangunan Nasional Peraturan Presiden Republik Indonesia Nomor 2 Tahun 2015 tentang Rencana Pembangunan Jangka Menengah Nasional Tahun 2015-2019. 
nelayan dilarang untuk menangkap ikan (Daud Djubedi, 2014:69). Sedangkan ngasi adalah salah satu pranata budaya masyarakat Halmahera Selatan yang diterapkan dalam bentuk pungutan, seperti pungutan yang diambil dari orang yang melakukan pelanggaran adat atau pungutan yang diambil dari orang yang memanfaatkan sumber daya alam pada komunitas adat tertentu (Daud Djubedi, 2014:72).

Tantangan yang dihadapi oleh Negara Indonesia sebagai negara kepulauan dengan luasnya wilayah maritim adalah percepatan pembangunan kelautan yang dapat dicapai dengan menjadikan Indonesia sebagai poros maritim dunia. Untuk menjadi poros maritim dunia, Indonesia harus dapat menegakkan kedaulatan dan yurisdiksi nasional; mengembangkan industri kelautan, industri perikanan, perniagaan laut; mendayagunakan potensi laut dan dasar laut bagi kesejahteraan rakyat Indonesia; dan menjaga daya dukung dan kelestarian fungsi lingkungan laut. ${ }^{32}$ Selain itu, penguasaan negara berdasarkan hukum tertulis dan penguasaan oleh masyarakat hukum adat berdasarkan hukum adat atau hukum yang tidak tertulis juga rawan menjadi potensi konflik sumber daya alam, terutama kaitannya dengan izin yang dikeluarkan oleh pemerintah untuk mengeksploitasi sumber daya laut di wilayah masyarakat hukum adat tanpa sepengetahuan dan izin dari masyarakat hukum adat yang bersangkutan.

\section{Kesimpulan}

Penguasaan Kerajaan Sriwijaya dan Kerajaan Majapahit terhadap wilayah maritimnya dilakukan melalui hukum adat. Kerajaan Sriwijaya menguasai wilayah maritimnya melalui hukum adat "paksaan menimbun barang" yang mewajibkan kapal-kapal singgah ke pelabuhannya, sehingga Raja Kerajaan Sriwijaya dapat memungut bea dari perdagangan yang melalui wilayah maritim Sriwijaya. Kebiasaan Kerajaan Sriwijaya melakukan ekspansi wilayah ditujukan untuk memperluas jaringan perdagangan kerajaan, sehingga hukum adat "paksaan menimbun barang" dapat berlaku bagi daerah yang ditaklukan. Kerajaan Majapahit melakukan penguasaan terhadap wilayah maritimnya melalui hukum adat yang kemudian dikodifikasi dalam buku Negarakertagama. Negarakertagama mengatur bahwa tugas dari angkatan laut Kerajaan Majapahit adalah untuk melindungi daerah bawahan dan menghukum pembesar daerah yang membangkang terhadap hukum Kerajaan Majapahit.

Persatuan wilayah maritim Indonesia yang menjadi dasar kemerdekaan Republik Indonesia terinspirasi dari kejayaan Kerajaan Sriwijaya dan Kerajaan Majapahit dalam mempersatukan Nusantara. Beberapa prinsip pengaturan wilayah maritim Indonesia saat ini dapat dijumpai juga dalam prinsip pengaturan wilayah maritim pada zaman Kerajaan Sriwijaya dan Kerajaan

32) Buku I Peraturan Presiden Republik Indonesia Nomor 2 Tahun 2015 tentang Rencana Pembangunan Jangka Menengah Nasional Tahun 2015-2019. 
Majapahit, seperti penyerahan urusan pemerintahan dari Pemerintah Pusat ke pemerintah daerah dan pengenaan bea terhadap kapal yang singgah pelabuhan. Meskipun demikian, tulisan ini belum mampu untuk menjawab apakah penganturan wilayah maritim Indonesia saat ini sepenuhnya berasal dari sejarah Kerajaan Sriwijaya dan Kerajaan Majapahit karena dalam perkembangaannya hukum di Indonesia banyak dipengaruhi oleh hukum Belanda dan hukum internasional. Di Indonesia hari ini, hukum yang berlaku bagi wilayah maritim tidak hanya hukum yang dibuat oleh negara atau hukum tertulis, namun hukum tidak tertulis, yaitu hukum yang hidup di masyarakat. Kedua hukum tersebut berinteraksi secara dinamis satu sama lain, terkadang saling mendukung, namun tidak jarang juga saling berkonflik.

\section{Referensi}

\section{Buku}

C. Dewi Wulansari (2012). Hukum Adat Indonesia Suatu Pengantar, Cetakan Ke-II, Bandung: Refika Aditama.

Cahyo Gumilang, dkk (Peny.) (2013). Pancasila Dasar Negara Kursus Pancasila oleh Presiden Soekarno. Yogyakarta: Pusat Studi Pancasila Universitas Gadjah Mada.

D. Negarayati Siregar (Peny.) (2001). Ketahanan Nasional Indonesia Penangkal Disintegrasi Bangsa dan Negara. Jakarta: Pustaka Sinar Harapan.

Daud Djubedi (2014). Hak Ulayat Laut di Era Otonomi Daerah. Yogyakarta: Genta Press.

Djoko Suryo dan Darmanto (Peny.) (2014). Peran DIY Dalam NKRI yang Berbudaya Maritim- Agraris-Niaga (MAN), Yogyakarta: Dewan Riset Daerah.

Hilman Hadikusuma (1978). Sejarah Hukum Adat Indonesia, Bandung: Alumni.

Irawan Djoko Nugroho (2011). Majapahit Peradaban Maritim Ketika Nusantara Menjadi Pengendali Pelabuhan Dunia, Jakarta: Yayasan Suluh Nuswantara Bakti.

Irwan Djoko Nugroho (2010). Meluruskan Sejarah Majapahit. Yogyakarta: Ragam Media. Jakarta: Balai Pustaka.

Kaelan (2013). Negara Kebangsaan Pancasila: Kultural, Historis, Filosofis, Yuridis dan Aktualisasinya, Yogyakarta: Paradigma.

Marwati Djoened Poesponegoro dan Marwati Djoened (1984). Sejarah Nasional Indonesia,

Megandaru W. Kawuryan (2006). Tata Pemerintahan Negara Kertagama Keraton Majapahit, Jakarta: Panji Pustaka.

Miriam Budiarjo (1981). Dasar-Dasar Ilmu Politik. Jakarta: Gramedia.

O.W. Wolters (1970). The Fall of Srivijaya Malay History. London: Oxford University Press.

Peter Mahmud Marzuki (2005). Penelitian Hukum, Jakarta: Prenada Media.

R. Soekmono (2002). Pengantar Sejarah Kebudayan Indonesia, Yogyakarta: Kanisius.

Slamet Mulyana (1979). Negarakertagama dan Tafsir Sejarahnya, Jakarta: Bhratara Karya Aksara

Soeroso M.P. Achadiati S. (1988). Sejarah Peradaban Manusia: Zaman Majapahit, 
Jakarta: PT Gita Karya.

Warsito Sastroprajitno (1958). Rekonstruksi Sedjarah Indonesia, Zaman Hindu, Yavadvipa, Srivijaya, Sailendara. Yogyakarta: PT Pertjetakan Republik Indonesia.

Zainuddin Ali (2014). Metode Penelitian Hukum, Cetakan Ke-V, Jakarta: Sinar Grafika.

\section{Laporan Penelitian}

Safri Burhanuddin, dkk. (2003). Sejarah Maritim Indonesia: Menelusuri Jiwa Bahari Bangsa Indonesia dalam Proses Integrasi Bangsa (Sejak Jaman Prasejarah Hingga Abad XVII)", (Laporan Penelitian, Pusat Kajian Sejarah dan Budaya Maritim Asia Tenggara Lembaga Penelitan Universitas Diponegoro bekerjasama dengan Pusat Riset Wilayah Laut dan Sumberdaya Non Hayati Badan Riset Kelautan Perikanan (BRKP) Departemen Kelautan dan Perikanan, Semarang).

\section{Makalah}

Widodo Putro (2017). 'Peta Mazhab Hukum dan Metode Penelitiannya. Makalah. Disampaikan pada Workshop Legal Research for Intermediate di Fakultas Hukum Universitas Gadjah Mada, 2-3 Oktober 2017.

Casparis, J.G. de Some Notes (1990). 'Relation between Central and Local Government in Ancient Java'. Makalah, dalam David G. Marr and A.C. Miller (Peny.). Southeast Asia in the $9^{\text {th }}$ to $14^{\text {th }}$ Centuries, Singapore: Chong Moh Offset Printing Private Limited, hlm. 51-52.

\section{Peraturan Perundang-Undangan}

Undang-Undang Dasar Negara Republik Indonesia Tahun 1945.

Undang-Undang Nomor 23 Tahun 2014 tentang Pemerintahan Daerah (Lembaran Negara Republik Indonesia Tahun 2014 Nomor 244, Tambahan Lembaran Negara Republik Indonesia Nomor 5587).

Undang-Undang Nomor 2 Tahun 2015 tentang Penetapan Peraturan Pemerintah Pengganti Undang-Undang Nomor 2 Tahun 2014 tentang Perubahan atas Undang-Undang Nomor 23 Tahun 2014 tentang Pemerintahan Daerah Menjadi Undang-Undang (Lembaran Negara Republik Indonesia Tahun 2014 Nomor 246, Tambahan Lembaran Negara Republik Indonesia Nomor 5589).

Undang-Undang Nomor 9 Tahun 2015 tentang Perubahan Kedua atas UndangUndang Nomor 23 Tahun 2014 tentang Pemerintahan Daerah (Lembaran Negara Republik Indonesia Tahun 2015 Nomor 58, Tambahan Lembaran Negara Republik Indonesia Nomor 5679).

Peraturan Pemerintah Pengganti Undang-Undang Nomor 4 Tahun 1960 tentang Perairan Indonesia (Lembaran Negara Nomor 22 Tahun 1960).

Peraturan Pemerintah Pengganti Undang-Undang Nomor 1 Tahun 2000 tentang Kawasan Perdagangan Bebas dan Pelabuhan Bebas (Lembaran Negara Republik Indonesia Tahun 2000 Nomor 147).

Peraturan Pemerintah Pengganti Undang-Undang Nomor 2 Tahun 2000 tentang Kawasan Perdagangan Bebas dan Pelabuhan Bebas Sabang (Lembaran Negara Republik Indonesia Tahun 2000 Nomor 148). 
Peraturan Pemerintah Republik Indonesia Nomor 46 Tahun 2007 tentang Kawasan Perdagangan Bebas dan Pelabuhan Bebas Batam (Lembaran Negara Republik Indonesia Tahun 2007 Nomor 46).

Peraturan Pemerintah Republik Indonesia Nomor 47 Tahun 2007 tentang Kawasan Perdagangan Bebas dan Pelabuhan Bebas Bintan (Lembaran Negara Republik Indonesia Tahun 2007 Nomor 47).

Peraturan Pemerintah Republik Indonesia Nomor 48 Tahun 2007 tentang Kawasan Perdagangan Bebas dan Pelabuhan Bebas Karimun (Lembaran Negara Republik Indonesia Tahun 2007 Nomor 48).

Peraturan Pemerintah Republik Indonesia Nomor 65 Tahun 2014 tentang Penyelenggaraan Kegiatan di Bandar Udara Hang Nadim Batam oleh Badan Pengusahaan Kawasan Perdagangan Bebas dan Pelabuhan Bebas Batam (Lembaran Negara Republik Indonesia Tahun 2014 Nomor 183, Tambahan Lembaran Negara Republik Indonesia Nomor 5569).

Peraturan Presiden Republik Indonesia Nomor 2 Tahun 2015 tentang Rencana Pembangunan Jangka Menengah Nasional Tahun 2015-2019 (Lembaran Negara Republik Indonesia Tahun 2015 Nomor 3).

\section{Internet}

http://www.kompasiana.com/rokhmin/indonesia-sebagai-poros-maritimdunia_54f97e43a3331178178b4f62 (diakses 10-03-2016).

http://jurnalmaritim.com/2014/11/strategi-maritim-untuk-pertahananindonesia/ (diakses 10-03-2016).

http://nasional.kompas.com/read/2014/10/09/22145401/Maksimalkan.Sisi. Maritim.Indonesia.Bisa.Lebih.Maju.dari.Majapahit.dan.Sriwijaya (diakses 11-03-2016).

http://nasional.news.viva.co.id/news/read/637865-kerajaan-majapahit-dijagalima-gugus-kapal-perang (diakses 02-09-2016).

http://nasional.news.viva.co.id/news/read/637865-kerajaan-majapahit-dijagalima-gugus-kapal-perang (diakses 02-09- 2016).

http://forum.viva.co.id/indeks/threads/lomba-thread-puluhan-jutarupiah.2226108/s://tni-au.mil.id/pustaka/australia-makin-gundahdengan-modernisasi-alutsista-tni-au (diakses 02-09-2016). 